\title{
Ascidians (Tunicata, Ascidiacea): species distribution along the Scotia Arc*
}

\author{
MARCOS TATIÀN ${ }^{1,2}$, JULIETA CAROLINA ANTACLI ${ }^{1}$ and RICARDO SAHADE ${ }^{1,2}$ \\ ${ }^{1}$ Ecología Marina. Facultad de Ciencias Exactas, Físicas y Naturales, Universidad Nacional de Córdoba, Argentina. \\ E-mail: mtatian@com.uncor.edu \\ ${ }^{2}$ CONICET-Instituto Antártico Argentino.
}

\begin{abstract}
SUMMARY: Ascidians are found in all the oceans. The Polar Front is considered a strong barrier, especially for benthic organisms, separating the Southern Ocean from other oceans. Its influence on ascidian species present at the boundary of the Magellan and Antarctic regions along the Scotia Arc and on the species composition at each station is inferred from the samples taken during the "LAMPOS" cruise. Ascidians were collected by Agassiz (AGT) and bottom (GSN) trawls at depths between 250 and $587 \mathrm{~m}$ on different types of substrate. Of 25 identified species/morphospecies one is new and eight were found in new localities, enlarging the known range of five of these species. Muddy bottoms were found to support higher species richness than hard bottoms, and the South Georgia Islands are found to be the northern limit for Antarctic species and the southern limit for Magellan ones. Affinity between the ascidian fauna of the Magellan region and the Antarctic is slightly stronger than was previously considered; there is also a species gradient along the Scotia Arc, which can be regarded as a bridge between the two regions.
\end{abstract}

Keywords: Tunicata, Scotia Arc, Polar Front, biogeography.

RESUMEN: Ascidias (Tunicata, Ascidiacea): distribución específica a lo largo del ArCo de Scotia. - Las ascidias habitan todos los mares. Considerado como una barrera especialmente para los organismos del bentos, el Frente Polar separa al Océano Austral del resto de los océanos. A partir de la composición de especies colectadas en cada estación durante el crucero "LAMPOS", se infiere la influencia del Frente Polar sobre las especies de ascidias presentes en el límite entre las regiones magallánica y antártica a lo largo del Arco de Scotia. Los ejemplares fueron colectados mediante rastra Agassiz y red de fondo entre 250 y $587 \mathrm{~m}$, en tipos diferentes de sustrato. De un total de 25 especies/morfoespecies identificadas, una es nueva mientras que ocho fueron encontradas en nuevas localidades extendiendo el rango de distribución conocido para cinco de ellas. Se encontró una mayor riqueza de especies sobre fondos lodosos que sobre fondos duros. Las islas Georgias del Sur constituyen el límite norte para las especies antárticas y el límite sur para las magallánicas. Las afinidades entre la ascidiofauna de las regiones magallánica y antártica son ligeramente mayores de lo que se consideraba, existiendo un gradiente a lo largo de las islas del Arco de Scotia, las cuales constituirían un puente biogeográfico entre dichas áreas.

Palabras clave: Tunicata, Arco de Scotia, Frente Polar, biogeografía.

\section{INTRODUCTION}

Ascidians occur in all the oceans, from the intertidal to the abyssal plain. There are several studies on ascidian biodiversity in the Southern Ocean (Herdman, 1882, 1886; Sluiter, 1906; Hartmeyer, 1912;

*Received March 31, 2004. Accepted March 10, 2005.
Ärnbäck-Christie-Linde, 1938, 1950; Millar, 1960; Kott 1969a, b, 1971), the most important recent study being that of Monniot and Monniot (1983). According to these authors, affinities between the ascidian fauna from the tip of South America and the Antarctic are low. A look at the Scotia Arc suggests that it might be a bridge between these two areas, in spite of the geographic distance, currents and the 
presence of the Polar Front. The Polar Front (Antarctic Convergence) is an irregular but permanent barrier (Hedgpeth, 1969; Boltovskoy, 1981) which contributes to the isolation of the fauna of Antarctic waters, limiting the migration from and into northern areas. For pelagic fauna this front may rather represent a transitional area (Clarke and Crame, 1989). The distribution of benthic sessile fauna depends on dispersal abilities of larval or even pre-larval stages such as gametes, eggs and embryos, which in turn can be affected by various factors: hydrology (salinity, temperature, currents and suspended material), depth and bottom type (Clarke, 1996). The influence of the Polar Front on the dispersal of sessile species like ascidians, characterised by short-lived and lecithotrophic larvae, is still unknown. While many ascidian species disappear just at the Polar Front, there are several species with a range extending across the Polar Front such as Aplidium falklandicum (Sahade et al., 2003). New records on the Scotia Arc must improve the knowledge on ascidian biodiversity and distribution, contributing to the biogeography of the study area.

\section{MATERIALS AND METHODS}

Samples were taken during the "LAMPOS" cruise (ANT XIX/5) of RV "Polarstern" in April 2002. Ascidians were collected by Agassiz (AGT) and bottom (GSN) trawls at depths between 250 and $587 \mathrm{~m}$ on different types of substrate (Table 1). For the gear characteristics see the LAMPOS cruise report (Arntz and Brey, 2003). Living animals were photographed to record their colour, which is lost on fixation. Animals were relaxed in seawater and later fixed in buffered formalin-seawater $4 \%$. Species were examined with a stereoscope and a compound microscope. The reproductive status of colonial species was recorded, including the presence of larvae. The examined material is in the Museo de Zoología, Facultad de Ciencias Exactas Físicas y Naturales, Universidad Nacional de Córdoba, Argentina.

Multivariate analyses were used to determine species affinity between localities. Classification was performed using the UPGMA clustering method (Bray-Curtis similarity). In addition, our data were pooled with previous data reported by Monniot and Monniot (1983), corresponding to the species distribution in the sampling area at depths of up to $1,000 \mathrm{~m}$. A similarity matrix was constructed with the pooled dataset, using the Kulczynski-2 index (Monniot and Monniot, 1983).

\section{RESULTS AND DISCUSSION}

\section{Species recorded}

25 species/morphospecies were found at the different stations sampled during the cruise, solitaries being slightly more abundant than colonial forms. One species is new, and eight were found in new

TABLE 1. - Stations sampled during the cruise.

\begin{tabular}{|c|c|c|c|c|}
\hline $\mathrm{N}^{\mathrm{o}}$ Station / Gear & Locality & Lat / long & Depth & substrate \\
\hline 145/AGT & Burdwood Bank & $54^{\circ} 1.36^{\prime} \mathrm{S} / 62^{\circ} 1.33^{\prime} \mathrm{W}$ & $272 \mathrm{~m}$ & gravel \\
\hline 150/AGT & Burdwood Bank & $54^{\circ} 30.22^{\prime} \mathrm{S} / 56^{\circ} 8.20^{\prime} \mathrm{W}$ & $286 \mathrm{~m}$ & gravel \\
\hline $153 / \mathrm{GSN}$ & Burdwood Bank & $54^{\circ} 31.22^{\prime} \mathrm{S} / 56^{\circ} 8.93^{\prime} \mathrm{W}$ & $296 \mathrm{~m}$ & gravel \\
\hline 160/AGT & Burdwood Bank & $53^{\circ} 23.75^{\prime} \mathrm{S} / 44^{\circ} 45.12^{\prime} \mathrm{W}$ & $435 \mathrm{~m}$ & gravel \\
\hline 164/AGT & Shag Rocks & $53^{\circ} 23.8^{\prime} \mathrm{S} / 42^{\circ} 42.03^{\prime} \mathrm{W}$ & $313 \mathrm{~m}$ & gravel \\
\hline $167 / G S N$ & Shag Rocks & $53^{\circ} 23.68^{\prime} \mathrm{S} / 42^{\circ} 42.23^{\prime} \mathrm{W}$ & $306 \mathrm{~m}$ & gravel \\
\hline $174 / G S N$ & South Georgia & $54^{\circ} 24.47^{\prime} \mathrm{S} / 35^{\circ} 36.81^{\prime} \mathrm{W}$ & $278 \mathrm{~m}$ & mud \\
\hline 182/AGT & South Georgia & $54^{\circ} 27.63^{\prime} \mathrm{S} / 35^{\circ} 41.33^{\prime} \mathrm{W}$ & $249 \mathrm{~m}$ & mud \\
\hline 187/AGT & South Sandwich & $55^{\circ} 56.08^{\prime} \mathrm{S} / 28^{\circ} 7.51^{\prime} \mathrm{W}$ & $255 \mathrm{~m}$ & volcanic stones \\
\hline 194/AGT & South Sandwich & $57^{\circ} 40.55^{\prime} \mathrm{S} / 26^{\circ} 25.14^{\prime} \mathrm{W}$ & $309 \mathrm{~m}$ & volcanic stones \\
\hline 196/GSN & South Sandwich & $57^{\circ} 40.6^{\prime} \mathrm{S} / 26^{\circ} 25.42^{\prime} \mathrm{W}$ & $301 \mathrm{~m}$ & volcanic stones \\
\hline 207/AGT & South Sandwich & $57^{\circ} 40.36^{\prime} \mathrm{S} / 26^{\circ} 27.89^{\prime} \mathrm{W}$ & $587 \mathrm{~m}$ & volcanic stones \\
\hline 208/GSN & South Sandwich & $57^{\circ} 40.25^{\prime} \mathrm{S} / 26^{\circ} 27.97^{\prime} \mathrm{W}$ & $630 \mathrm{~m}$ & volcanic stones \\
\hline 214/AGT & South Sandwich & $59^{\circ} 42.55^{\prime} \mathrm{S} / 27^{\circ} 57.02^{\prime} \mathrm{W}$ & $332 \mathrm{~m}$ & pebbles \\
\hline 217/AGT & Herdman Bank & $59^{\circ} 54.98^{\prime} \mathrm{S} / 32^{\circ} 28.33^{\prime} \mathrm{W}$ & $521 \mathrm{~m}$ & pebbles \\
\hline $229 / \mathrm{GSN}$ & Discovery Bank & $60^{\circ} 8.77^{\prime} \mathrm{S} / 34^{\circ} 54.83^{\prime} \mathrm{W}$ & $371 \mathrm{~m}$ & pebbles \\
\hline 231/AGT & South Orkneys & $60^{\circ} 59.19^{\prime} \mathrm{S} / 43^{\circ} 27.42^{\prime} \mathrm{W}$ & $402 \mathrm{~m}$ & mud \\
\hline 238/AGT & South Orkneys & $61^{\circ} 10.81^{\prime} \mathrm{S} / 45^{\circ} 42.72^{\prime} \mathrm{W}$ & $322 \mathrm{~m}$ & mud \\
\hline $241 / \mathrm{GSN}$ & South Orkneys & $61^{\circ} 11.15^{\prime} \mathrm{S} / 45^{\circ} 43.84^{\prime} \mathrm{W}$ & $323 \mathrm{~m}$ & mud \\
\hline 252/AGT & Elephant Is. & $61^{\circ} 23.45^{\prime} \mathrm{S} / 55^{\circ} 26.82^{\prime} \mathrm{W}$ & $285 \mathrm{~m}$ & mud \\
\hline $253 / \mathrm{GSN}$ & Elephant Is. & $61^{\circ} 23.40^{\prime} \mathrm{S} / 55^{\circ} 26.99^{\prime} \mathrm{W}$ & $282 \mathrm{~m}$ & mud \\
\hline
\end{tabular}


TABLE 2. - Known distribution range of the species found (including only distribution from Antarctic Peninsula to Magellan through the Scotia Arc) and new records. * From Monniot and Monniot (1983). APS: Antarctic Peninsula, South Shetland Islands and Elephant I.

\begin{tabular}{|c|c|c|}
\hline Species & Distribution range* & New records \\
\hline Aplidium falklandicum Millar, 1960 & Widely, from APS to Magellan & \\
\hline Aplidium globosum (Herdman, 1886) & South Orkneys, South Sandwich & Elephant I., Burdwood Bank \\
\hline Aplidium polarsterni $\mathrm{n} . \mathrm{sp}$. & & Burdwood Bank \\
\hline Synoicum adareanum (Herdman, 1902) & APS, South Orkneys & \\
\hline Synoicum georgianum Sluiter, 1932 & APS to Magellan & \\
\hline Polyclinidae sp. & & Burdwood Bank \\
\hline Protoholozoa pedunculata Kott, 1969 & South Orkneys & \\
\hline Cystodytes antarcticus Sluiter, 1912 & APS & Burdwood Bank \\
\hline Tetrazona glareosa (Sluiter, 1906) & APS, South Sandwich & Burdwood Bank \\
\hline Distaplia cylindrica (Lesson, 1830) & Widely, from APS to Magellan & \\
\hline Polysyncraton trivolutum (Millar, 1960) & APS, South Georgia, Magellan & S. Orkneys \\
\hline Tylobranchion speciosum Herdman, 1886 & Widely, from APS to Magellan & \\
\hline Cibacapsa gulosa Monniot and Monniot, 1983 & & S. Sandwich \\
\hline Caenagnesia bocki Ärnbäck-Christie-Linde, 1938 & APS, South Sandwich, South Georgia & \\
\hline Ascidia meridionalis Herdman, 1880 & South Georgia, Magellan & \\
\hline Styelidae sp. & & Shag Rocks \\
\hline Cnemidocarpa verrucosa (Lesson, 1830) & Widely, from APS to Magellan & \\
\hline Cnemidocarpa drygalskii (Hartmeyer, 1911) & APS & Herdman, Discovery and Burdwood Bank \\
\hline Pyura bouvetensis (Michaelsen, 1904) & APS, South Orkneys & \\
\hline Pyura discoveryi (Herdman, 1910) & APS, South Orkneys, South Georgia & \\
\hline Pyura georgiana (Michaelsen, 1898) & South Georgia & \\
\hline Pyura squamata Hartmeyer, 1911 & APS, South Orkneys & Shag Rocks \\
\hline Molgula pedunculata Herdman, 1881 & From APS to South Georgia & \\
\hline Molgula hodgsoni Herdman, 1910 & APS, South Orkneys, South Georgia & \\
\hline Eugyrioides polyducta Monniot and Monniot, 1983 & APS, South Sandwich, South Georgia & \\
\hline
\end{tabular}

localities, extending the known range of five of these species (Table 2). Ascidians were a commonly collected group, being present in more than $80 \%$ of the captures; however the abundance was low, with usually only a few individuals per sample. 11 families were found, the most common being Polyclinidae (6 species) and Pyuridae (4 species). Muddy bottoms were found to support higher species richness than hard bottoms such as gravel, pebbles and volcanic stones.

\section{List of species}

Order APLOUSOBRANCHIA Lahille, 1887 Family POLYCLINIDAE Verrill, 1871

\section{Aplidium falklandicum Millar, 1960}

Aplidium falklandicum Millar, 1960: 34, Pl. I 3-4, Fig. 3 A-H; Monniot and Monniot, 1983: 15 (synonymy).

Examined material: St. 182: 14 colonies; St. 231: 13 colonies; St. 253: 2 colonies.

The morphology of the colonies and zooids agrees with Millar (1960), although he observed a maximum of seven stomach folds, whereas our specimens have up to eight. The most relevant feature, not reported before, is the intense yellowlemon colour seen in live colonies, which is replaced by a dark grey colour after preservation.
Larvae were present; according to Millar (1960), this species breeds throughout the year.

\section{Aplidium globosum (Herdman, 1886)}

Amaroucium globosum Herdman, 1886: 219, Pl. 24, Fig. 1-5; Monniot and Gaill, 1978: 143, Fig. 3 C, D (type revision); Monniot and Monniot, 1983: 17 (synonymy).

Examined material: St. 145: 3 colonies; St. 153: 2 colonies; St. 252: 7 colonies.

Zooids reach a large size (up to $1.3 \mathrm{~cm}$ ) with an atrial languet, two- or three-lobed. The stomach folds vary in number from six to eight. Larvae were present. A parasitic copepod was observed in the atrial cavity of one of the zooids.

\section{Aplidium polarsterni $\mathrm{n}$. sp.}

(Fig. 1 A, B, C)

Type locality: Burdwood Bank (St. 145), 54 $2^{\circ}$ 'S 62 $0,5^{\prime} \mathrm{W} ; 272 \mathrm{~m}$, 5/IV/ 02. Holotype: (MZUC VIIIa 00001) Museo de Zoología, Facultad de Ciencias Exactas Físicas y Naturales, Universidad Nacional de Córdoba, Argentina.

Etymology: from "Polarstern" research vessel of the Alfred Wegener Institute, Germany.

Examined material: St. 145: 2 colonies.

Description: The round shaped colonies are thinner at the base, with one short stalk or sessile. The colonies have only one head. The colour in life and 


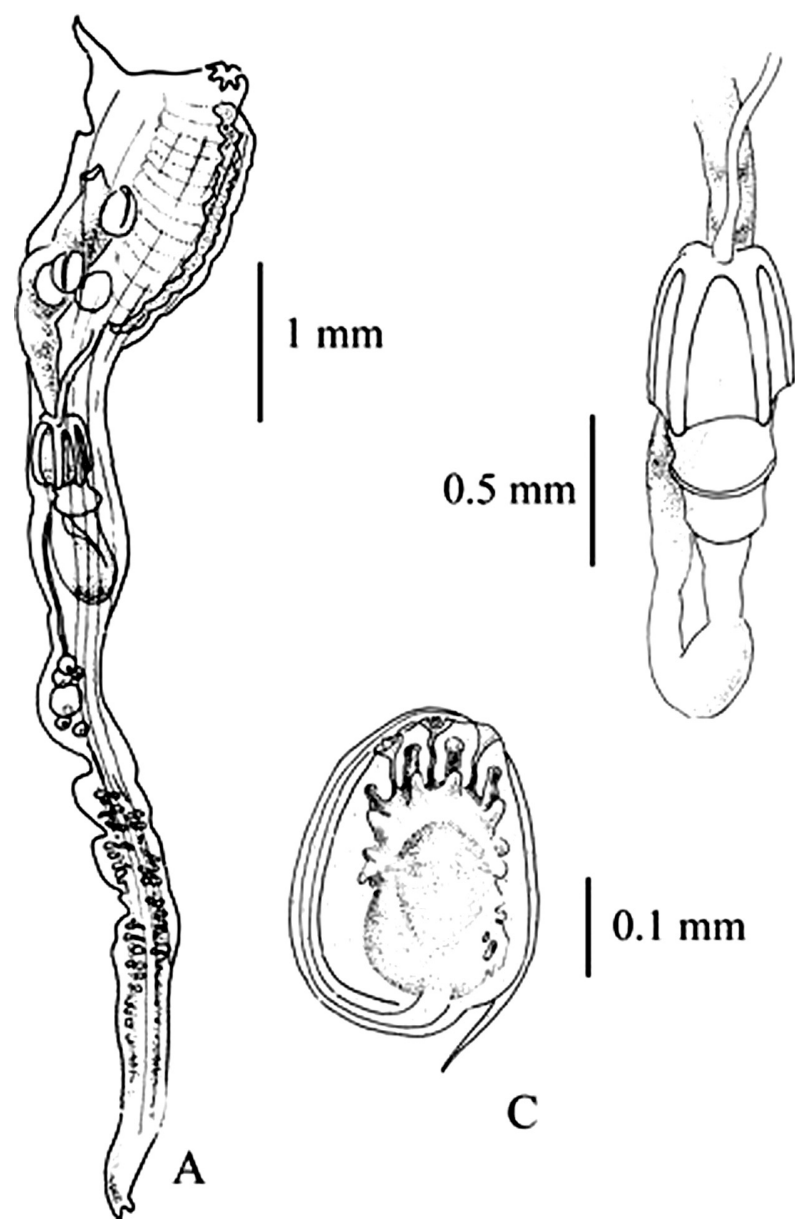

FIG. 1. - Aplidium polarsterni n. sp. A: zooid. B: larva. C: gut.

after fixation is transparent. The tunic is smooth, gelatinous and soft. Particles of sand (most of them coarse, quartz-like particles) are dispersedly arranged, internally and externally, but are mostly at the base. There are epibionts (bryozoans and small corals) attached to the base of the colony. The length of the colonies reaches $2.5 \mathrm{~cm}$.

The zooids, evident through the tunic, are large, pale orange in colour and not arranged in clear systems, the common cloacal apertures not being evident. The total length of the zooids, when they are not contracted, reaches $10 \mathrm{~mm}$. The thorax and abdomen are of approximately the same length: the thorax varies from 1 to $3 \mathrm{~mm}$, the abdomen from 1 to $2.5 \mathrm{~mm}$. The post-abdomen is of variable length, from 1.5 to $5 \mathrm{~mm}$. The musculature is well developed with about eight longitudinal strong muscle bands, which run along either side of the body from the thorax to the posterior end of the post-abdomen, where they are still conspicuous. The oral siphon is terminal, with six sharp lobes. The atrial siphon is a small aperture situated at the level of the first or third stigmata row, which is provided by a long atrial languet from the anterior border of the opening, single or with two or three lobes (with the central lobe more developed). The branchial sac is narrow, with a total of 12-13 stigmata rows, with at least 12 stigmata per row on each side. The oesophagus is slender and very long; the stomach, situated in the middle of the abdomen, is cylindrical or trapezoidal, with five or six deep folds which continue along the whole length of the stomach. There is a marked post-stomach provided by a post-stomachal disc; situated on or very close to the intestinal loop, there is a stilted mid-intestine. The anus lies just at the level of the seventh or eighth stigmata row. The gonads are located in lateral widening of the post abdomen, B at a short distance from the intestinal loop or even very far from it, at the middle of the post-abdomen. The ovary has a variable number of follicles of different size, depending on the colony and zooid. The testis follicles are arranged in single or double rows along the extension of the post-abdomen.

Colonies were full of larvae, reaching up to 15 larvae in the peribranchial cavity of a single zooid. The ovoid trunk is $0.3-0.5 \mathrm{~mm}$ long and $0.2-0.3 \mathrm{~mm}$ wide. A long tail extends nearly the whole distance around the body. There are three long anterior adhesive papillae provided by slender stalks alternating with four broad median ampullae. There is also a crown composed of at least four pairs of lateral ampullae. Both ocellus and otolith are present.

Remarks: This species has affinities with Aplidium undulatum Monniot and Gaill (1978), which also has colonies embedded in sand particles and zooids with a similar number of stigmata rows and stomach folds. Nevertheless, the zooids of A. undulatum do not have strong thoracic muscle bands. The oral siphon shows small lobes, and the aperture of the atrial siphon is wide, extending up to the sixth stigmata row. The post-stomach is absent or poorly marked. The species Aplidium globosum has a similar appearance in shape, colour and size to A. polarsterni, but the colonies do not include sand particles. In A. globosum the zooids are arranged in systems around a common cloaca. They also have small oral lobes, their stomach folds are discontinuous, and teh testis follicles are always arranged in a single row.

\section{Synoicum adareanum (Herdman, 1902)}

Polyclinum adareanum Herdman, 1902: 194; Monniot F., 1978: 4 (synonymy); Monniot and Monniot, 1983: 31; Monniot and Monniot, 1994: 18; Tatián et al., 1998a: 148; 1998b: 112, Fig. 2 B. 
The larvae are present and arranged in brood pouches enclosed in the internal test, as was described by Kott (1969a). This species was previously found at shallower depths, between 5 and 90 m (Herdman, 1902; Monniot F., 1970, 1978; Monniot and Monniot, 1974; Vasseur, 1974a, b).

\section{Synoicum georgianum Sluiter, 1932}

Synoicum georgianum Sluiter, 1932: 11, Fig. 9-10; Monniot and Monniot, 1983: 32 (synonymy).

Examined material: St. 253, 5 colonies.

Sand particles, algae and bryozoans are attached to the colonies. There is a high variability in the shape of the stomach: in our specimens the stomach is cubic, rhomboid, oval or enlarged longitudinally, always big and with the wall smooth or striated transversally. No larvae were found.

\section{Polyclinidae sp.}

Examined material: St. 145: 2 colonies; St. 153: 1 colony; St. 231: 1 colony.

The colonies are cushion-shaped, with one or two heads. They are up to $3 \mathrm{~cm}$ high and $4 \mathrm{~cm}$ wide. The tunic is firm and tough. The colour is transparent to ochre. The zooids are distinguishable through the tunic, arranged in parallel rows at different levels along the colony. No common cloaca is evident. There are sand particles and shell fragments attached to the base of the colony.

The zooids were immature or in dormant stage, between 0.2 and $10 \mathrm{~mm}$ length, with the body divided into thorax, abdomen and post-abdomen. Apertures, branchial sac, digestive tract and gonads were not developed.

Family PolyCITORIDAe Michaelsen, 1904

Protoholozoa pedunculata Kott, 1969

Protoholozoa pedunculata Kott, 1969a: 35, Fig. 17-20; Monniot and Monniot, 1982: 103, Pl. 1 C, Fig. 3 (type revision); Monniot and Monniot, 1983: 36, Pl. V A (synonymy).

Examined material: St. 217: 5 colonies; St. 223: 5 colonies.

The zooids had larvae, which reached a size of up to $0.5 \mathrm{~cm}$; presence of embryos was previously reported in October (Kott, 1969a). Species show a wide bathymetric distribution, from $374 \mathrm{~m}$ (the present finding) down to abyssal depths (2818-5000 m Kott, 1969a).

\section{Cystodytes antarcticus Sluiter, 1912}

Cystodytes antarcticus Sluiter, 1912: 460; Monniot and Monniot, 1983: 36 (synonymy).

Examined material: St. 150: 2 colonies.

With larvae, up to $2 \mathrm{~mm}$ size.

Tetrazona glareosa (Sluiter, 1906)

Distoma glareosa Sluiter, 1906: 6, Pl. 1, Fig. 1-4. Monniot and Monniot, 1983: 37 Pl. III G, Fig. 6 E-G (synonymy).

Examined material: St 145: 2 colonies.

Fresh colonies are red-indigo, colour becomes transparent in preservation. The tunic has calcaric spicules of variable shape. In most cases larvae were bigger than zooids. This finding enlarges the bathymetric range for the species (previously up to $100 \mathrm{~m}$ ).

Family Holozoidae Berril, 1950

Distaplia cylindrica (Lesson, 1830)

Holozoa cylindrica Lesson, 1830: 439 ; Monniot and Monniot, 1983: 36 (synonymy); Tatián et al., 1998a: 149 ; 1998b: 113, Fig. 2 E.

Examined material: St. 174: 1 colony; St. 182: 1 colony; St. 241: 7 colonies.

In many colonies zooids are male, female and undifferentiated (young or in relapse posterior to sexual period). Larvae were present.

Family DidEMNIDAE Giard, 1872

Polysyncraton trivolutum (Millar, 1960)

Didemnum trivolutum Millar, 1960: 58, Fig. 12; Monniot and Monniot, 1983: 43, Pl. IV A-D; Fig. 8 A-H (synonymy); Monniot and Monniot, 1994: 18.

Examined material: St. 182: 5 colonies; St. 231: 3 colonies.

The colonies are incrusted on little rocks, bryozoans and sponges. The maximum size of the lateral spreading is $13 \mathrm{~cm}$. The tunic is about $4 \mathrm{~mm}$ thick and is embedded with spicules, mainly in the superficial layer and around the zooids, these parts of the colony turning white. Spicules have a size of 18 to $24 \mu \mathrm{m}$ : their form is stellate, with no more than 20 conical rays in a medial plane, rounded or bluntly pointed. There were larvae (up to $2 \mathrm{~mm}$ size). 
Order PHLEBoBRANCHIA Lahille, 1887

Family CIONIDAE Lahille, 1887

Tylobranchion speciosum Herdman, 1886

Tylobranchion speciosum Herdman, 1886: 157, Pl. XXII 1-17; Monniot and Monniot, 1983: 50, Pl. IV F, I (synonymy); Monniot and Monniot, 1994: 119; Tatián et al., 1998a: 149; 1998b: 113, Fig. $2 \mathrm{~F}$.

Examined material: St. 194: 3 colonies; St. 196: 1 colony.

The colonies are attached to little rocks and gorgonians, with epibiotic algae and hydrozoans.

Family OCTACNEMIdAe Herdman, 1888

Cibacapsa gulosa Monniot and Monniot, 1983

Cibacapsa gulosa Monniot and Monniot, 1983: 50, Pl. IV G, H, Fig. 10; Monniot and Monniot, 1994: 28.

Examined material: St. 207: 3 specimens.

This is a species known from the Ross and Weddell Sea and South of Kerguelen (Monniot and Monniot, 1983, 1994). The present is the first record for the Scotia Arc (South Sandwich Islands).

Family AgNesiIdAe Huntsman, 1912 Caenagnesia bocki Ärnbäck-Christie-Linde, 1938

Caenagnesia bocki Ärnbäck-Christie-Linde, 1938: 41, Pl. 2 Fig. 2022; Monniot and Monniot, 1983: 60, Fig. 11 G (synonymy).

Examined material: St 252: 1 specimen.

The tunic is uniformly covered with sand, mud, bryozoans, foraminifers and gastropods.

Family AscidiIDAE Adams, 1858

Ascidia meridionalis Herdman, 1880

Ascidia meridionalis Herdman, 1880: 465; Monniot and Monniot, 1983: 62, Fig. 12 A-E (synonymy).

Examined material: St. 150: 2 specimens; St. 153: 5 specimens; St. 160: 2 specimens; St. 164: 4 specimens.

The specimens show epibionts: bryozoans, polychaete tubes and algae. They are also covered by inorganic material, sponge spicules and sand particles. The gonads are composed of rounded testis follicles, joined or separate, covering the stomach, mainly in the posterior $2 / 3$ of the body. The ovary follicles are small and yellow, arranged in irregular rows on the intestinal loop. Full gonoducts revealed the advanced reproductive state of the individuals (spawning). Renal vesicles are arranged around the gonads and the digestive tract.

\author{
Order StolidobRanchia Lahille, 1887 \\ Family STYELIDAE Sluiter, 1895 \\ Styelidae sp.
}

Examined material: St. 164: 1 specimen.

The identification of the main characters was possible, but the gonadal structure was not. Epibiont of Ascidia meridionalis, the sole specimen collected at Shag Rocks may be a young specimen because of the small size $(0.5 \mathrm{~cm}$ height, $0.8 \mathrm{~cm}$ width) and the little development of the gonads and the digestive tract.

\section{Cnemidocarpa verrucosa (Lesson, 1830)}

Cynthia verrucosa Lesson, 1830: 151; Monniot and Monniot, 1983: 68, Pl. VII A-C (synonymy); Monniot and Monniot, 1994: 32. Tatián et al., 1998a: 149; 1998b: 113, Fig. 2 I.

Examined material: St. 174: 2 specimens; St. 182: 1 specimen; St. 187: 1 specimen.

There was a high variability in shape and colour among specimens collected at South Georgia and South Sandwich. The former are of large size (up to $20 \mathrm{~cm}$ ), whitish, with both apertures very developed, the oral situated anteriorly. The tunic is provided with spines ending in multiple points. The specimen collected in South Sandwich was red-orange alive, brown-red when preserved. Apertures are both sessile and located at the same level. The tunic has rounded conical papillae.

\section{Cnemidocarpa drygalskii (Hartmeyer, 1911)}

Tethyum drygalskii Hartmeyer, 1911: 452, Pl. 45, Fig. 6; Monniot and Monniot, 1983: 69, Fig. 13 C, D (synonymy).

Examined material: St. 153: 1 specimen; St. 217: 2 specimens; St. 229: 1 specimen.

Family PYURIDAE Hartmeyer, 1908

Pyura georgiana (Michaelsen, 1898)

Boltenia georgiana Michaelsen, 1898: 364; Monniot and Monniot, 1983: 88, Pl. VI D, Fig. 19 A (synonymy).

Examined material: St. 182: 4 specimens.

The present record extends the bathymetric range of this endemic species from the South Georgia Islands to $300 \mathrm{~m}$ depth. Variable epibionts include hydrozoans, bryozoans and algae; particles of sand were also observed on the tunic.

Pyura bouvetensis (Michaelsen, 1904)

Boltenia bouvetensis Michaelsen, 1904: 216, Pl. 10, Fig. 6. Monniot and Monniot, 1983: 88 Pl. VI E, F, Fig. 18 D (synonymy); Monniot and Monniot, 1994: 33. Tatián et al., 1998a: 150; 1998b: 113: Fig. 2 L. 
Examined material: St. 231: 3 specimens; St. 241: 1 specimen; St. 252: 4 specimens; St. 253: 14 specimens.

\section{Pyura discoveryi (Herdman, 1910)}

Halocynthia discoveryi Herdman, 1910: 9; Monniot and Monniot, 1983: 96 (synonymy); Monniot and Monniot, 1994: 34. Tatián et al., 1998a: 150; 1998b: 113, Fig. 2 K.

Examined material: St. 174: 1 specimen ; St. 182: 5 specimens.

The specimens have epibionts at the base of the body: hydrozoans, bryozoans, bivalve shells, algae. There are sand particles adhered mainly to the base and close to the apertures.

\section{Pyura squamata Hartmeyer, 1911}

Pyura squamata Hartmeyer, 1909-1911: 1337 (nomen nudum); 1911: 439, Pl. 45 12, Pl. 50 1-5; Monniot and Monniot, 1983: 95 Fig. 20 A (synonymy); Monniot and Monniot, 1994: 34.

Examined material: St. 164: 1 specimen.

Although this specimen had five branchial folds at each side of its body, the published number of folds for this species is five well developed ones with a rudimentary sixth fold (Millar, 1960; Monniot and Monniot, 1983).

Family Molgulidae Lacaze-Duthiers, 1877 Molgula pedunculata Herdman, 1881

Molgula pedunculata Herdman, 1881: 234; Monniot and Monniot, 1983: 98 (synonymy); Monniot and Monniot, 1994: 35; Tatián et al., 1998a: 150 Fig. 2 b, 3 a-c; 1998b: 113.

Examined material: St. 174: 2 specimens; St. 182: 2 specimens; St. 253: 1 specimen.

Specimens with epibionts: hydrozoans and algae.

\section{Molgula hodgsoni Herdman, 1910}

Molgula hodgsoni Herdman, 1910: 11, Pl. 3 Fig. 7B; Monniot and Monniot 1983: 99, Pl. VII G (synonymy); Monniot and Monniot, 1994: 34.

Examined material: St. 174: 4 specimens; St. 182: 5 specimens; St. 231: 1 specimen.

Description: The shape is nearly spherical, reaching a height of 1.3 to $2.4 \mathrm{~cm}$ and a width of 1.2 to 2 $\mathrm{cm}$. The colour is transparent, the tunic is slender but resistant, showing abundant extensions similar to hairs. Algae, polychaetes, sponge spicules, foraminifers and sand particles are adhered mainly to the right side of the tunic. Both siphons are situated at the same level in the corners of the anterior part of the body. Some are conspicuous and others not. The mantle is thin. It is possible to see the internal organs by transparence. The musculature is strong: 16 to 20 longitudinal bands radiate from each aperture onto both sides of the body; they are interrupted at the anterior middle of the body (at the level of the visceral mass in the left side). Transverse bands are thinner, abundant in the siphons; some intercrossed in the body wall. The oral siphon is six-lobed, the cloacal siphon is four-lobed, both apertures have an internal velum. There are 15-16 oral tentacles in three different sizes, placed between and branched in three orders. The dorsal tubercle is C-shaped, opening to the left side, sometimes with curved horns, always inward. The dorsal lamina is short and narrow with a smooth margin or large with transverse grooves, wider in the posterior part. The branchial sac has a variable number of folds: in specimens from 1.5 to $2.3 \mathrm{~cm}$ height we found 7 folds on each side, but only 6 folds on the right side in specimens from 1.3 to $2.4 \mathrm{~cm}$, and finally a total of 6 folds on both sides in one specimen of $2.2 \mathrm{~cm}$. Folds located dorsally are mainly elevated, the ventral ones flat and arranged close to one another. There are 4-13 longitudinal vessels in the folds and 1-7 between folds. Some are branched. In one specimen $(2.4 \mathrm{~cm}$ height $)$ it was possible to observe the following arrangement of folds and longitudinal vessels:

On the right side: DL 5 (8) 6 (9) 5 (9) 6 (10) 6 (8) 5 (8) 2 (9) $2 \mathrm{E}$

On the left side: DL 1 (11) 6 (12) 5 (7) 5 (9) 6 (11) 5 (10) 5 (7) $2 \mathrm{E}$

There are transverse vessels at each side of the body separated by some thinner ones, and discontinuous parastigmatic vessels. The stigmata are straight, 5-7 per mesh. In some parts (at the base of the folds, in the joint of the folds and close to the wider transverse vessels) stigmata were lightly curved, not forming infundibula. The digestive tract is placed along the major part of the left side, with a long and narrow esophagus and a round or oval stomach covered by hepatic diverticula. The intestine is close to the endostyle, making a closed primary loop and a secondary curve very pronounced, followed by a very long rectum which is overlapped by the stomach, finishing in one smooth anus. Both hermaphrodite gonads are joined to the kidney and the intestine, respectively, by their posterior tip. The ovary is central and composed of small round follicles, yellow colour, covered by bigger and pyriform testis follicles, white colour, joined in many bunches. The oviduct is short, conspicuous and situated at the dorsal tip of the gonad; the sperm duct, less developed, opens beside the ovary. The kidney is transparent, sometimes curved. 
Remarks: This species has been confused with small specimens of Molgula pedunculata (Millar, 1960; Kott, 1969a). Published literature always described the presence of seven folds on each side (Herdman, 1910; Ärnbäck-Christie-Linde, 1938; Millar, 1960; Monniot C., 1978). In some of our specimens there are only six, independent of the animal size. Monniot and Monniot (1983) saw " 6 clean folds", but described a total of seven folds when they showed the number of longitudinal vessels. Some authors have seen infundibula (Kott, 1969a; Monniot and Monniot, 1983), whereas Herdman (1910) did not.

\section{Eugyrioides polyducta \\ Monniot and Monniot, 1983}

Eugyrioides polyducta Monniot and Monniot, 1983: 115, Pl. VII H, Fig. 24 D; Monniot and Monniot, 1994: 35.

Examined material: St. 252: 17 specimens

The tunic is covered by sand and mud particles and epibionts such as sponges and hydrozoans. The ovary is constituted by rounded follicles, while the testis follicles are arranged at the dorsal ridge of the ovary. The kidney is small and inconspicuous.

\section{Biogeography}

Species composition of the stations sampled was related to substrate type: cluster analysis divided the stations into 4 groups (Fig. 2). Group A and B contained samples from South Sandwich stations (volcanic stones, hard bottoms) that were characterised by a low number of species which caused the separation of the other groups. Group C comprised stations belonging to the Antarctic and Magellan banks (hard substrates). Group D included soft substrate stations from South Georgia, South Orkney and South Shetland Islands. Sub-groups clustered samples of close localities, i.e. Burdwood Bank and Shag Rocks $\left(\mathrm{c}_{1}\right)$, Herdman and Discovery Banks $\left(c_{2}\right)$; South Orkney and South Shetland $\left(\mathrm{d}_{1}\right)$ and South Georgia and South Sandwich $\left(\mathrm{d}_{2}\right)$. Stations were grouped mainly by substrate type and then by geographical distance or region. Substrate type appears to be an important factor in ascidian distribution. Molgulids usually settle on soft substrates (Monniot and Monniot, 2001), and the same is true for some widely distributed Antarctic species such as Distaplia cylindrica or Caenagnesia bocki (Van Name, 1945; Millar, 1960; Kott, 1969a); these

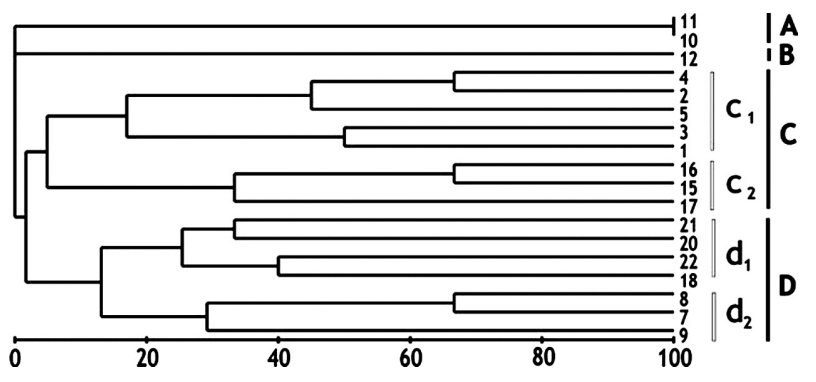

FIG. 2. - Cluster analysis of species at different localities. Groups formed are indicated with capital letters; sub-groups, indicated in lower-case letters (stations: 1-5: Burdwood Bank, Shag Rocks; 7-8 South Georgia; 9-12: South Sandwich; 15-17: Herdman and Discovery Banks; 18-20: South Orkneys; 21-22: South Shetland). Stations without ascidians were not included in the analysis.

species, together with the molgulids Molgula pedunculata, Molgula hodgsoni and Eugyrioides polyduc$t a$, were found exclusively on muddy bottoms.

The second cluster included previous data (Monniot and Monniot, 1983) and those from the present study (Fig. 3). It showed 2 main groups: group A included Antarctic localities (South Georgia, South Sandwich, South Orkney and South Shetland), and group B included samples from the Magellan Province. Sub-groups clustered samples of close localities: South Sandwich and South Georgia Islands $\left(a_{1}\right)$ and South Shetland and South Orkney Islands $\left(\mathrm{a}_{2}\right)$. In this case with more samples and species, biogeographic region and distance seems to better explain the cluster analyses. Faunistic affinities using the pooled data-set (our data plus previous data) among different localities were compared with those calculated by Monniot and Monniot (1983). Table 3 reveals a gradient from Magellan to Antarctica along the Scotia Arc, in terms of their ascidian fauna. Nevertheless, the addition of six species to Magellan situated this area closer to the islands of the Scotia Arc than had been previously considered.

Stations belonging to the Magellan Province (Burdwood Bank, Shag Rocks) were similar. Only 3 species (Aplidium globosum, Polyclinidae sp. and Cnemidocarpa drygalskii) from a total of 9 found at these stations were also found in other localities.

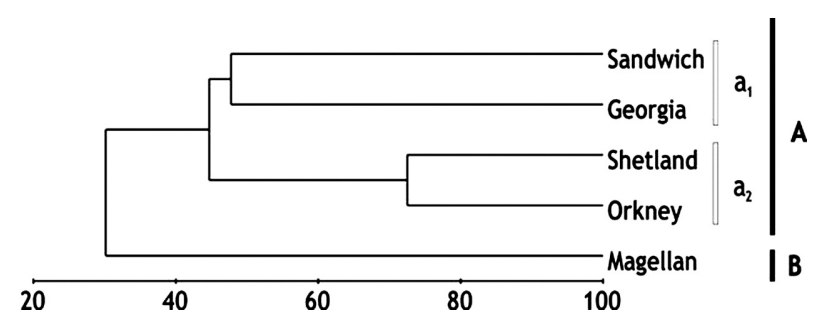

FIG. 3. - Cluster analysis of species at different localities. Pooled data from the present study and those from Monniot and Monniot (1983). Groups are indicated in upper case, sub-groups in lower case. 
TABLE 3. - Similarity index between different localities. APS: pooled data from Antarctic Peninsula, South Shetland Islands and Elephant I. Ts: similarities calculated in this study; Ps: similarities calculated in a previous study by Monniot and Monniot (1983).

\begin{tabular}{|c|c|c|c|c|c|c|c|c|}
\hline & \multicolumn{2}{|c|}{ Magellan } & \multicolumn{2}{|c|}{ S. Georgia } & \multicolumn{2}{|c|}{ S. Sandwich } & \multicolumn{2}{|c|}{ S. Orkneys } \\
\hline & Ts & Ps & Ts & Ps & Ts & Ps & Ts & Ps \\
\hline S. Georgia & $45 \%$ & $42 \%$ & - & - & - & - & - & - \\
\hline S. Sandwich & $29 \%$ & $25 \%$ & $47 \%$ & $49 \%$ & - & - & - & - \\
\hline S. Orkney & $35 \%$ & $27 \%$ & $45 \%$ & $44 \%$ & $41 \%$ & $43 \%$ & - & - \\
\hline APS & $33 \%$ & $27 \%$ & $48 \%$ & $47 \%$ & $45 \%$ & $44 \%$ & $69 \%$ & $65 \%$ \\
\hline
\end{tabular}

Some Subantarctic species are replaced in the Polar Front: Ascidia meridionalis is distributed along the Patagonian shelf to the South Georgia Islands, were it is replaced by Ascidia challengeri, which is absent in South American waters (Millar, 1960; Kott, 1969a; Monniot and Monniot, 1983).

The Polar Front seems to be an effective barrier to the dispersal of ascidians and the Scotia Arc islands could be a bridge for the colonisation of Antarctica (or vice-versa), as also suggested for other faunal groups (Clarke and Crame, 1989). Particularly interesting is the position of the South Georgia islands, since they represent the northernmost limit of exclusively Antarctic species and the southernmost of Magellan species, showing similar affinities to both the Antarctic and the Magellan region (Table 3). These distribution patterns, following the stepping stone model, suggest a fluctuating position of the Polar Front. Thus, as observed during the LAMPOS cruise but in contrast to most publications on the subject, the South Georgia Islands may be at the north of the Polar Front. This alternating position may cause considerable instability for shallow-water benthos.

\section{ACKNOWLEDGEMENTS}

The authors thank the "Polarstern" crew and Prof Dr. Wolf Arntz (AWI). They are indebted to three anonymous reviewers whose suggestions greatly improved the manuscript. This work was supported by the Alfred Wegener Institute, Instituto Antartico Argentino, CONICET, Universidad Nacional de Córdoba and Fundación Antorchas.

\section{REFERENCES}

Arntz, W.E. and T. Brey. - 2003. The expedition Antarktis XIX/5 (LAMPOS) of RV "Polarstern" in 2002. Ber. Polar-Meeresforsch. 462: 1-120.

Ärnbäck-Christie-Linde, A. - 1938. Ascidiacea Part 1. Further
Zool. Res. Swedish Antarct. Exp., 3(4): 1-54.

Ärnbäck-Christie-Linde, A. - 1950. Ascidiacea Part 2. Further Zool. Res. Swedish Antarct. Exp., 3 sér., 13(3): 1-91.

Boltovskoy, D. - 1981. Características biológicas del Atlántico sudoccidental. In: D. Boltovskoy (ed.), Atlas del zooplancton del Atlántico sudoccidental y métodos de trabajo con el zooplancton marino, pp. 239-251, INIDEP, Buenos Aires.

Clarke, A. - 1996. The distribution of Antarctic marine benthic communities. Ant. Res. Ser., 70: 219-230.

Clarke, A. and J.A. Crame. - 1989. The origin of the Southern Ocean marine fauna. In: Origins and evolution of the Antarctic biota. Geological Society Special Publication, 47: 253-268.

Hartmeyer, R. - 1909/1911. Ascidien. In: Bronn, H.G., Klassen und Ordnungen des Tier-Reichs. Leipzig Suppl. 3: 81-98 and 1281-1773.

Hartmeyer, R. - 1911. Die Ascidien der deutschen Südpolar-Expedition 1901-1903. Deutsche Südpolar-Exped., 12(4, Zool.): 403-606.

Hartmeyer, R. - 1912. Die Ascidien der deutschen Tiefsee-Expedition. In: Wiss. Ergebn. Dt. Tiefsee-Exped. Valdivia 1898-1899, 16(3): 225-392.

Hedgpeth, J.W. - 1969. Introduction to Antarctic zoogeography. In: Distribution of selected groups of marine invertebrates in waters south of $35^{\circ}$ S latitude. Antarctic Map Folio Ser., American Geographical Society, 11: 1-9.

Herdman, W.A. - 1880. Preliminary report on the Tunicata of the "Challenger" Expedition. Part. 1. - P. Roy. Soc. Edinb., 10: 458-472.

Herdman, W.A. - 1881. Preliminary report on the Tunicata of the "Challenger" Expedition. Part. 4. - P. Roy. Soc. Edinb., 11: 233-240.

Herdman, W.A. - 1882. Report on the Tunicata collected during the voyage of H.MS. "Challenger" during the years 1873-1876. Part. I. Ascidiae simplices. Rep. sci. Res. Voy. H.M.S. "Challenger". Zool., 6(17): 1-296.

Herdman, W.A. - 1886. Report on the Tunicata collected during the voyage of H.M.S. "Challenger" during the years 1873-1876. Part. II. Ascidiae compositae, and Appendix A. Supplementary report upon the Ascidias simplices, and Appendix B. Description of a new species of Psammaplidium. Rep. sci. Res. Voy. H.MS. "Challenger". Zool., 14(38): 1-432.

Herdman, W.A. - 1902. Tunicata. In: Report on the collections of natural history made in the Antarctic regions during the voyage of the "Southern Cross". London: 190-200.

Herdman, W.A. - 1910. Tunicata. - National Antarctic Expedition (S.S. Discovery) 1901-1904, Nat. Hist., 5: 1-26.

Kott, P. - 1969a. Antarctic Ascidiacea. Antarct. Res. Ser., 13: 1-239.

Kott, P. - 1969b. Ascidiacea. In: Distribution of selected groups of marine invertebrates in waters south of $35^{\circ} \mathrm{S}$ latitude. Antarctic Map Folio Ser., American Geographical Society, 11: 43-44.

Kott, P. - 1971. Antarctic Ascidiacea II. Antarct. Res. Ser., 17: 11-82.

Lesson, R.P. - 1830. Zoologie. Voyage autour du monde sur la corvette La Coquille pendant 1822-1825. Paris, 2(1), 1-471.

Michaelsen, W. - 1898. Vorläufige Mitteilung über einige Tunicaten aus dem Magalhaensischen Gebiet, sowie von SüdGeorgien. Zool . Anz., 21: 363-371.

Michaelsen, W. - 1904. Die stolidobranchiaten Ascidien der deutschen Tiefsee-Expedition. Wiss Ergebn. deutschen TiefseeExpedition auf dem Dampfer Valdivia, 1898-1899, 7(2): 181-260.

Millar, R.H. - 1960. Ascidiacea. Discov. Rep., 30: 1-160.

Monniot, C. - 1978. Ascidies Phlébobranches et Stolidobranches du Sud de l'Océan Indien. Ann. Inst. Océanogr., Paris, 54(2): 171-224. 
Monniot, C. and F. Monniot. - 1974. Ascidies de la $22^{\mathrm{e}}$ Expédition Antarctique Chilienne. Bol. Soc. Biol. Concepción, 48: 365-383.

Monniot, C. and F. Monniot. - 1982. Antarctic deep-sea tunicates in the Smithsonian collections. Antarct. Res. Ser, 32: 95-130.

Monniot, C. and F. Monniot. - 1983. Ascidies antarctiques et subantarctiques: morphologie et biogéographie. Mém. Mus. Nat. Hist. Nat., Paris (A), 215: 1-135.

Monniot, C. and F. Monniot. - 1994. Ascidians collected in the Weddell Sea by the RV "Polarstern" (EPOS cruise leg 3). Bull. Mus. Nat. Hist Nat., Paris (A), 16: 13-37.

Monniot, C. and F. Monniot. - 2001. Ascidians from the tropical Western Pacific. Zoosystema, 23(2): 201-383.

Monniot, F. - 1970. Ascidies Aplausobranches des Îles Kerguelen récoltées par P. Grua. Bull. Mus. Nat. Hist. Nat., Paris, $2^{\mathrm{e}}$ Sér., 42(2): 321-339.

Monniot, F. - 1978. Revision des Polyclinidae (Ascidiacea) des $1^{\mathrm{e}}$ et $2^{\mathrm{e}}$ Expéditions Antarctiques Françaises décrites par $\mathrm{C}$. $\mathrm{Ph}$. Sluiter. Bull. Mus. Nat. Hist. Nat., Paris, 3e Sér. Zool., 351: 3-18.

Monniot, F. and F. Gaill. - 1978. Polyclinidae (Ascidiacea) du SudOuest de l'Océan Indien. Ann. Inst. Océanogr., Paris, 54(2): 139-162.

Sahade, R., M. Demarchi, M. Chiappero, M. Tatián and N. Gardenal. - 2003. Genetic differentiation between populations of the ascidian Aplidium falklandicum from South Georgia and South Orkney Islands. In: S. Thatje, J. Calcagno and W. Arntz (eds.), Interactions between the Magellan region and the Antarctic -
Antarctic benthic deep-sea biodiversity. Extended Abstracts of the IBMANT/ANDEEP International Symposium and Workshop: 95-96.

Sluiter, C.P. - 1906. Tuniciers. In: Expédition Antarctique Francaise 1903-1905. Bull. Mus. Nat. Hist. Nat., Paris, 6: 1-48.

Sluiter, C.P. - 1912. Les ascidiens de l'Expédition Antarctique Française du "Porquoi pas?" commandée par le Dr. J. Charcot, 1908-1909. Bull. Mus. Nat. Hist. Nat., Paris, 18(7): 452-460.

Sluiter, C.P. - 1932. Die von Dr. L. Kohl-Larsen gesammelten Ascidien von Süd-Georgien und den Steart-Inseln. Senckenbergiana, 14(1-2): 1-9.

Tatián, M., R. Sahade, M. Doucet and G.B. Esnal. - 1998a. Ascidians (Tunicata, Ascidiacea) of Potter Cove, South Shetland Islands, Antarctica. Ant. Sci. 10(2): 147-152.

Tatián, M., R. Sahade, M. Doucet and G.B. Esnal. - 1998b. Some aspects on Antarctic ascidians (Tunicata, Ascidiacea) of Potter Cove, King George Island. In: C. Wiencke, G. Ferreyra, W. Arntz and C. Rinaldi (eds.), The Potter Cove coastal ecosystem, Antarctica. Reports on Polar Research, 299: 113-118.

Van Name, W.G. - 1945. The North and South American ascidians. B. Am. Mus. Nat. Hist., 84: 1-476.

Vasseur, P. - 1974a. Ascidies. In: Invertébrés marins des XIIe et XVe expéditions antarctiques françaises en Terre Adélie. Tethys, 5(4) : 611-628.

Vasseur, P. - 1974b. Ascidies des Îles Kerguelen récoltées par J.C. Hureau. Tethys, 5(4): 735-746. 